\title{
Penyuluhan Pemanfaatan Obat Tradisional dan Pembuatan Hand Sanitizer dalam Pencegahan Covid-19 di Masyarakat Pulau Hiri
}

\author{
Amran Nur ${ }^{1 *}$, Ismail Rahman². \\ ${ }^{1}$ Program Farmasi, Fakultas Kedokteran, Universitas Khairun Ternate \\ ${ }^{2}$ Program Pendidikan Dokter, Fakultas Kedokteran, Universitas Khairun Ternate \\ email: amran.nur@unkhair.ac.id
}

\begin{abstract}
Hiri Island is located in the north of Ternate Island, internet access on the island is still lacking. This has an impact on the lack of information obtained by the people on Hiri Island, including information about the Covid-19 outbreak. the World health organization (WHO) stated that on January 30, 2020, the world had a Corona Virus Pandemic (Covid-19). Hiri Island has a variety of plants, so it is necessary to provide counseling to the community in the area regarding the use of natural ingredients as a traditional medicine in preventing transmission of the coronavirus, as well as providing information about the process of transmission of the virus, one of which transmission media is through hands. So it is necessary to make a handwashing product (hand sanitizer) to prevent transmission of the virus through hand media. In the implementation of the service, there was a change in the method, which initially socialization by gathering the community was changed to direct distribution of hand sanitizers as well as a short explanation to the public about the importance of hand hygiene and the importance of maintaining health by utilizing herbal medicines around the community. The results of this service show public awareness of the importance of cleanliness, especially hands by always washing hands or using hand sanitizers to prevent transmission of the Covid-19 virus and this activity has made the people of Hiri Island understand the benefits of traditional medicine to increase body immunity to avoid contracting the Covid-virus. 19
\end{abstract}

Keywords: Covid-19, Hand Sanitizer, Traditional Medicine, Hiri Island.

\begin{abstract}
Abstrak
Pulau Hiri terletak di utara Pulau Ternate, akses internet di pulau tersebut masih bisa dikatakan kurang. Hal itu berimbas pada minimnya informasi yang didapatkan oleh masyarakat di Pulau Hiri, termasuk informasi mengenai wabah Covid-19. World health organization (WHO) menyatakan pada Tanggal 30 Januari 2020 dunia sudah Pandemi Virus corona (Covid-19). Pulau Hiri memiliki tumbuhan yang beraneka ragam, maka perlu dilakukan penyuluhan kepada masyarakat di daerah tersebut tentang pemanfaatan bahan alam sebagai obat tradisional dalam mencegah penularan virus corona, serta pemberian informasi tentang proses penularan virus tersebut yang salah satu media penularannya adalah tangan. Maka perlu untuk membuat sebuah produk cuci tangan (hand sanitizer) guna mencegah penularan virus melalui media tangan. Pada pelaksanaan pengabdian terjadi perubahan metode yang awalnya sosialisasi dengan mengumpulkan masyarakat dirubah menjadi pembagian langsung handsanitizer sekaligus dirangkaikan penjelasan singkat kepada masyarakat tentang pentingnya kebersihan tangan dan pentingnya menjaga kesehatan dengan memanfaatkan obat herbal yang berada disekitar masyarakat. Hasil dari kegiatan pengabdian ini memperlihatkan kesadaran masyarakat tentang pentingnya kebersihan terutama tangan dengan selalu mencuci tangan atau menggunakan hand sanitizer untuk mencegah penularan virus Covid-19 serta kegitan ini menjadikan masyarakat Pulau Hiri memahami manfaat obat tradisional untuk meningkatkan imun tubuh agar terhindar dari tertularnya virus Covid-19
\end{abstract}

Kata Kunci: Covid-19, Hand Sanitizer, Obat Tradisional, Pulau Hiri 


\section{PENDAHULUAN}

Influenza, yang lebih dikenal dengan sebutan flu, merupakan penyakit menular yang disebabkan oleh virus RNA dari familia Orthomyxoviridae (virus influenza), yang menyerang unggas dan mamalia. Gejala yang paling umum dari penyakit ini adalah menggigil, demam, nyeri tenggorokan, nyeri otot, nyeri kepala berat, batuk, kelemahan, dan rasa tidak nyaman secara umum.[1]

Influenza menyebar ke seluruh dunia dalam epidemi musiman, yang menimbulkan kematian 250.000 dan 500.000 orang setiap tahunnya,[2] bahkan sampai jutaan orang pada beberapa tahun pandemik. Rata-rata 41.400 orang meninggal tiap tahunnya di Amerika Serikat dalam kurun waktu antara tahun 1979 sampai 2001 karena influenza.[3] Pada tahun 2010 Pusat Pengendalian dan Pencegahan Penyakit di Amerika Serikat mengubah cara mereka melaporkan perkiraan kematian karena influenza dalam 30 tahun. Saat ini mereka melaporkan bahwa terdapat kisaran angka kematian mulai dari 3.300 sampai 49.000 kematian per tahunnya.

Salah satu jenis penyakit flu yang sekarang menjadi headline di dunia adalah flu yang diakibatkan oleh Virus Corona. Koronavirus[1] atau coronavirus (istilah populernya: virus korona, virus corona, atau virus Corona) adalah sekumpulan virus dari subfamili Orthocoronavirinae dalam keluarga Coronaviridae dan ordo Nidovirales.[2] Kelompok virus ini yang dapat menyebabkan penyakit pada burung dan mamalia (termasuk manusia).[4] Pada manusia, koronavirus menyebabkan infeksi saluran pernapasan yang umumnya ringan, seperti pilek, meskipun beberapa bentuk penyakit seperti SARS, MERS, dan COVID-19 sifatnya lebih mematikan. Manifestasi klinis yang muncul cukup beragam pada spesies lain: pada ayam, koronavirus menyebabkan penyakit saluran pernapasan atas, sedangkan pada sapi dan babi menyebabkan diare. Belum ada vaksin atau obat antivirus untuk mencegah atau mengobati infeksi koronavirus pada manusia.[5]

Pandemi koronavirus 2019-2020 atau dikenal sebagai pandemi Covid-19 adalah peristiwa pandemi penyakit koronavirus 2019 (bahasa Inggris: coronavirus disease 2019, disingkat COVID-19). Penyakit ini disebabkan oleh koronavirus jenis baru yang diberi nama SARS-CoV-2.[1] COVID-19 pertama kali dideteksi di Kota Wuhan, Provinsi Hubei, Tiongkok pada bulan Desember 2019 setelah beberapa orang mengalami pneumonia tanpa sebab yang jelas dan prosedur perawatan dan vaksin yang diberikan ternyata tidak efektif.[6][5] Kemunculan penyakit diduga berhubungan dengan pasar grosir makanan laut Huanan yang menjual hewan hidup. Sedikitnya $70 \%$ urutan genom SARSCoV-2 sama seperti SARS-CoV.[7][5]

Wabah ini telah dinyatakan sebagai kedaruratan kesehatan masyarakat yang meresahkan dunia (PHEIC) oleh Organisasi Kesehatan Dunia (WHO) pada 30 Januari 2020.[6] Pernyataan ini adalah deklarasi keenam yang dilakukan oleh WHO sejak pandemi flu babi 2009. Xenophobia dan rasisme terhadap orangorang keturunan Tiongkok dan Asia Timur terjadi sebagai akibat dari wabah COVID19, dengan ketakutan dan permusuhan terjadi di beberapa negara.[8] Misinformasi tentang koronavirus yang menyebar terutama melalui internet membuat WHO menyatakan "infodemik" pada 2 Februari 2020[9]

Biasanya, virus Flu dalam hal ini termasuk virus corona ditularkan melalui udara lewat batuk atau bersin, yang akan menimbulkan aerosol yang mengandung virus. Influenza juga dapat ditularkan melalui kontak langsung dengan tinja burung atau ingus, atau melalui kontak dengan permukaan yang telah terkontaminasi.[10] [11]Virus influenza 
dapat diinaktivasi oleh sinar matahari, disinfektan, dan deterjen.[12] Sering mencuci tangan akan mengurangi risiko infeksi karena virus dapat diinaktivasi dengan sabun.[13], selain menggunakan cuci tangan penggunaan obat-obat tradisional juga dapat menghindari dari terserangnya penyakit flu[14][15]

Permasalahan yang dihadapi sekarang ini adalah kurangnya pengetahuan mengenai apa sebenarnya itu virus corona, seperti apa ciri-cirinya, dan yang terpenting bagaimana cara menghidari serta menangkal penularan virus tersebut, karena gejala flu yang diakibatkan oleh virus corona hampir sama dengan flu biasa, ditambah lagi dengan pemberitaan media sosial yang terkadang memberikan informasi yang kurang tepat (Hoax), sehingga masyarakat menjadi semakin takut tentang wabah tersebut, padahal bila masyarakat mengetahui cara pencegahannya, penularan virus tersebut bisa dihindari.

Maka dari itu perlu adanya kesadaran dan peran aktif dari para pihak yang terkait baik itu lembaga kesehatan dan pendidikan untuk memberikan edukasi kepada masyarakat mengenai wabah flu yang disebabkan virus corona tersebut, pemberian edukasi tersebut dilakukan dalam bentuk penyuluhan penggunaan obat-obatan yang berasal dari bahan alam yang dapat meningkatkan kekebalan tubuh terhadap virus tersebut serta memberikan pelatihan kepada masyarakat mengenai cara pembuatan cairan hand sanitizer, agar penularan melalui kontak langsung dalam hal ini bersentuhan tangan bisa di minimalisir.

\section{METODE PENGABDIAN}

Metode pendekatan serta solusi yang ditawarkan yaitu:

1. Melakukan penyuluhan kepada masyarakat tentang pemanfaatan obat tradisional berupa tumbuhan atapun tanamanan dari bahan alam yang berada di sekitar Pulau Hiri yang bermanfaat dalam meningkatkan sistem imun tubuh yang berguna mencegah penularan penyakit termasuk pencegahan penularan wabah virus korona.

2. Menjelaskan pentingnya senantiasa memelihara kebersihan tangan melalui pembuatan cairan cuci tangan (hand sanitzer) pada masyarakat Pulau Hiri yang bermanfaat dalam mencegah penularan penyakit khususnya wabah virus corona melalui media tangan.

\section{HASIL DAN PEMBAHASAN}

Pelaksanaan kegiatan pengabdian diawali dengan melakukan sosialisasi kepada mitra terkait kegiatan yang akan dilakukan di lokasi mitra. Sosialisasi yang dilakukan yaitu dengan menjelaskan maksud kegiatan pengabdian yaitu melakukan sosialisasi tentang manfaat obat tradisional dalam meningkatkan imun tubuh agar terhindar dari virus Covid-19 serta melaksanakan pembagian handsanitizer kepada masyarakat di Pulau Hiri

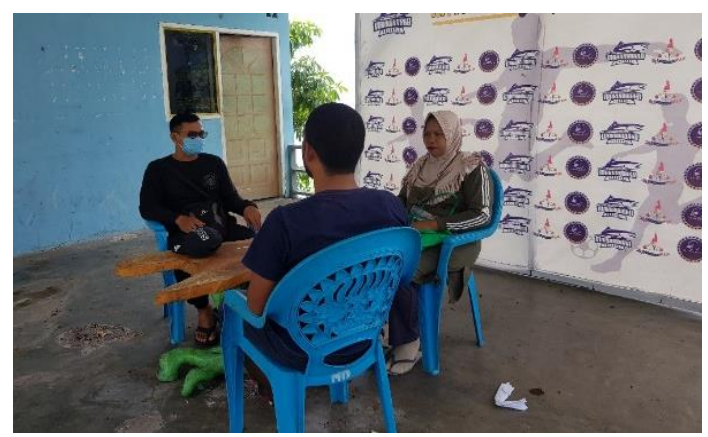

Gambar 1. Proses sosialisasi dengan Mitra Proses selanjutnya adalah penandatanganan kesediaan kerjasama dengan mitra terkait kesediaan mitra dalam kegiatan PKM. Selanjutnya setelah penandatanganan kerjasama dengan mita kami menetapkan jadwal pelaksanaan kegiatan, sehingga kami mendaptkan waktu pelaksanaan yang tepat. Sebelum dilaksanakan proses pengabdian kami pertama-tama menyiapkan hand sanitizer untuk nantinya dibagikan kepada masyarakat Pulau Hiri. Adapun target pembagian hand sanitizer adalah pada asyarakat sekitar pelabuhan Pulau Hiri serta 
di tempat fasilitas umum seperti mesjid dan daerah pelabuhan.
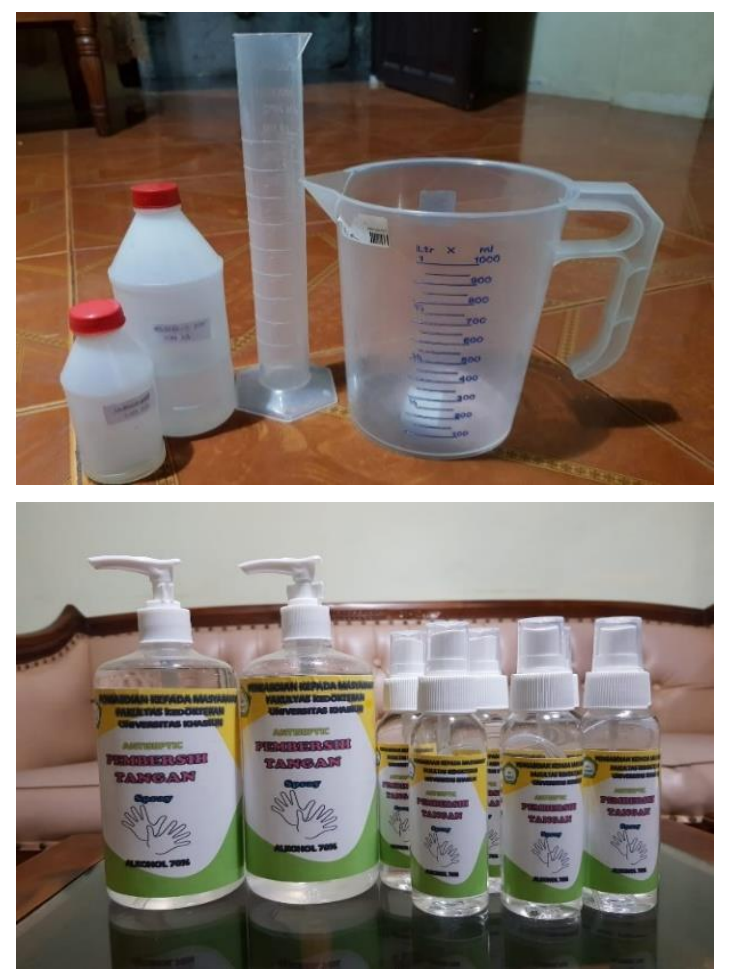

Gambar 2. Proses Pembuatan Hand sanitizer

Proses selanjutnya adalah proses pelaksanaan pengabdian di Pulau Hiri, sebelum melaksanakan pengabdian terlebih dahulu kami mengkoordinasikan jadwal yang tepat, dan tanggal 12 September 2020 menjadi waktu yang disepakati dengan pihak mitra.

Saat proses komunikasi dengan mitra, ada beberapa perubahan rencana, sebelumnya proses sosialisasi dilakukan dengan cara mengumpulkan warga di balai desa, mitra meminta agar proses tersebut dirubah menjadi langsung pembagian Handsanitizer karena mempetimbangkan situasi pandemi virus corona (Covid-19) yang belum redah, yang melarang adanya pengumpulan massa pada satu tempat, sehingga tim menyetujui hal tersebut ditiadakan dan langsung ke agenda pembagian hand sanitizer.

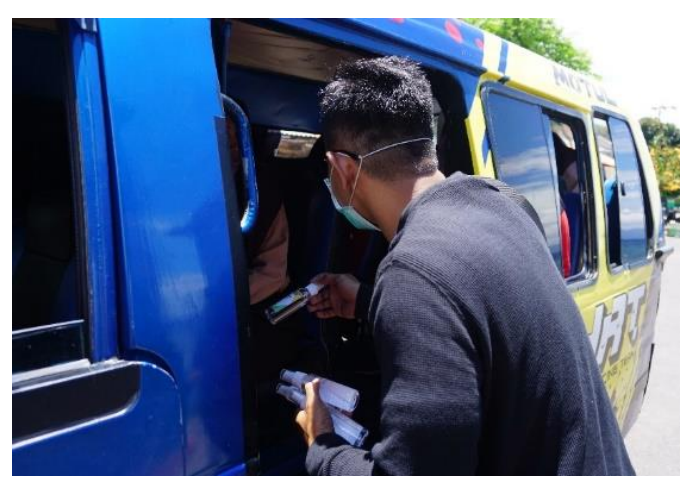

Gambar 3. Proses pembagian Hand Sanitizer

Proses Pembagian hand sanitizer berjalan dengan lancar dan masyarakat Pulau Hiri menyambut senang program pengabdian tersebut, masyarakat di Pulau Hiri juga mengharapkan agar kegiatan seperti ini selalu diadakan di sana, sebab hal tersebut sangatlah bermanfaat terlebih pada saat keadaan pandemi virus corona yang mengharuskan masyarakat lebih menjaga kebersihan tangan, pada saat pembagian hand sanitizer kami juga memberikan sosialisasi singkat mengenai cara mencuci tangan serta tumbuhan-tumbuhan yang berkhasiat meningkatkan imun tubuh, seperti jahe, kunyit, dan temulawak. [16]Manfaat tumbuhan tersebut sudah teruji sejak lama dan tumbuhan tersebut banyak digunakan secara empiris oleh masyarakat di Indonesia sebagai bahan dasar minuman ataupun jamu untuk meningkatkan sistem imun tubuh.[17][18] 

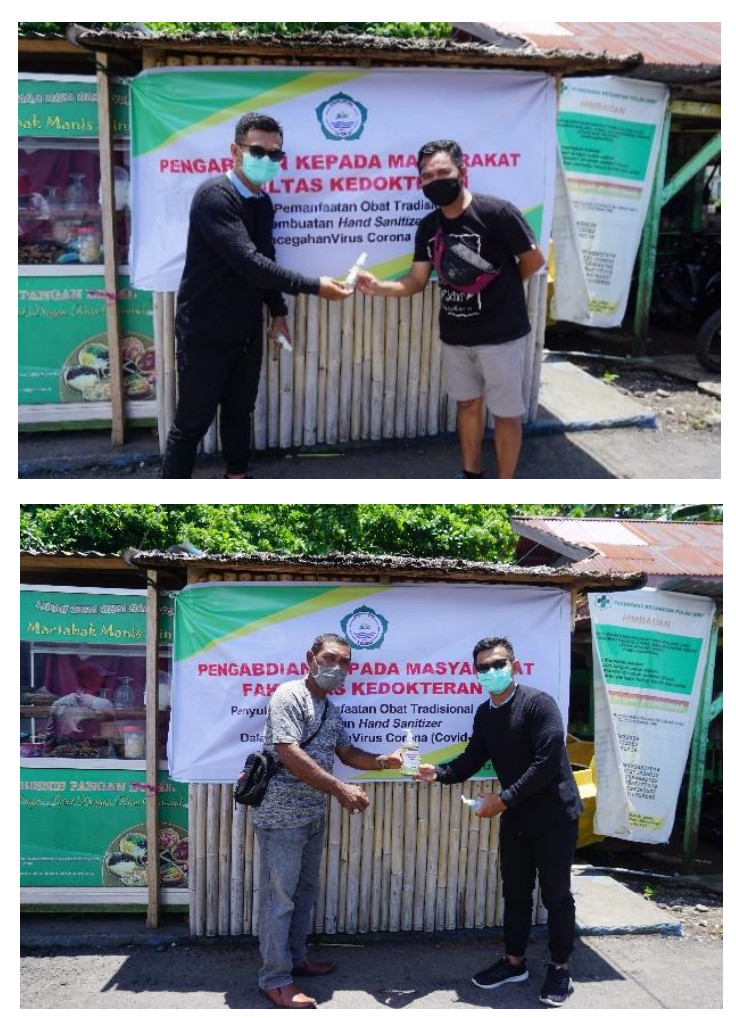

Gambar 4. Foto Pembagian Hand sanitizer dengan penduduk

\section{SIMPULAN}

Berdasarkan hasil kegiatan yang telah dilaksanakan mengenai penyuluhan pemanfaatan obat tradisional dan pembuatan hand sanitizer dalam pencegahan Covid-19 di masyarakat Pulau Hiri dapat disimpulkan kesadaran masyarakat tentang pencegahan wabah Covid-19 sudah baik, dapat dilihat dari antusiasme warga pada saat dilakukan pembagian hand sanitizer, dan pada proses pembagian hand sanitizer dilakukan juga edukasi mengenai manfaat tumbuhan di sekitar Pulau Hiri yang dapat dimanfaatkan sebagai obat tradisional untuk meningkatkan imun tubuh, contohnya seperti tumbuhan rempah yang banyak di Pulau Hiri dan masyarakat sangat terbantu oleh kegiatan ini.

\section{UCAPAN TERIMAKASIH}

Ucapan Terimakasih kami haturkan kepada mitra dalam hal ini lurah Pulau Hiri yang telah memberikan dukungan dalam terlaksananya pengabdian kepada masyarakat di Pulau Hiri, tak lupa juga kami haturkan terimakasih kepada pihak Universitas Khairun yang telah mendukung keberhasilan pengabdian ini.

\section{DAFTAR PUSTAKA}

[1] R. A. Bright et al., "Incidence of adamantane resistance among influenza A (H3N2) viruses isolated worldwide from 1994 to 2005: A cause for concern," Lancet, vol. 366, no. 9492, pp. 1175-1181, Oct. 2005.

[2] R. A. Weinstein and B. Hota, "Contamination, Disinfection, and Cross-Colonization: Are Hospital Surfaces Reservoirs for Nosocomial Infection?," Clin. Infect. Dis., vol. 39, no. 8, pp. 1182-1189, Oct. 2004.

[3] M. N. Ballinger and T. J. Standiford, "Postinfluenza bacterial pneumonia: Host defenses gone awry," Journal of Interferon and Cytokine Research, vol. 30, no. 9. pp. 643-652, 01-Sep-2010.

[4] B. Winther, J. M. Gwaltney, N. Mygind, and J. O. Hendley, "Viralinduced rhinitis," in American Journal of Rhinology, 1998, vol. 12, no. 1 , pp. 17-20.

[5] J. Griffiths and A. Woodyatt, "Wuhan coronavirus: Thousands of cases confirmed as China goes into emergency mode," CNN.

[6] J. Griffiths, "Wuhan coronavirus death toll rises to nine with 440 infected says China, sparking fears of wider spread," CNN, Jan. 2020.

[7] F. Li, W. Li, M. Farzan, and S. C. Harrison, "Structural biology: Structure of SARS coronavirus spike receptor-binding domain complexed with receptor," Science (80-. )., vol. 309, no. 5742, pp. 1864-1868, Sep. 2005.

[8] A. C. P. Wong, X. Li, S. K. P. Lau, and P. C. Y. Woo, "Global 
epidemiology of bat coronaviruses," Viruses, vol. 11, no. 2. MDPI AG, 01-Feb-2019.

[9]

"Wuhan lockdown 'unprecedented', shows commitment to contain virus: WHO representative in China," Reuters, Jan. 2020 .

[10] C. R. Maclntyre et al., "Face mask use and control of respiratory virus transmission in households," Emerg. Infect. Dis., vol. 15, no. 2, pp. 233-241, Feb. 2009.

[11] W. W. Thompson et al., "Influenzaassociated hospitalizations in the United States," J. Am. Med. Assoc., vol. 292, no. 11, pp. 1333-1340, Sep. 2004.

[12] R. J. Whitley and A. S. Monto, "Prevention and Treatment of Influenza in High- Risk Groups: Children, Pregnant Women, Immunocompromised Hosts, and Nursing Home Residents," J. Infect. Dis., vol. 194, no. s2, pp. S133S138, Nov. 2006.

[13] J. C. Kash et al., "Genomic analysis of increased host immune and cell death responses induced by 1918 influenza virus," Nature, vol. 443, no. 7111, pp. 578-581, Oct. 2006.

[14] N. F. Elis Susilawati, I Ketut Adnyana, "Studies On The Antidiabetic Activity Of Ethanol Extract And Its Fractions Of Singawalang (Petiveria Alliacea L.) Leaves In Mice," Pharmacy, Vol. 13, No. 02, Pp. 182-191, 2016.

[15] "Tanaman Obat untuk Influenza Dra. Herti Maryani \& Lusi Kristiana, Apt. - Google Buku." [Online]. Available: https://books.google.co.id/books?hl $=\mathrm{id} \& \mathrm{r}=\& \mathrm{id}=\mathrm{JZmZpCC} 5 \mathrm{bcc}$ \& \&oi $=$ fnd $\& p g=P P 12 \& d q=$ penyakit + influ enza\&ots=B6bDQ1Qjoh\&sig $=\mathrm{CM}$ Wm-8xd40s8I-

DcCymxbM4X8r0\&redir_esc $=y \# v$ $=$ onepage $\& \mathrm{q}=$ penyakit influenza\&f=false. [Accessed: 13Mar-2020].

[16] A. Nur, "Efek Analgetik Kombinasi Ekstrak Buah Belimbing Wuluh (Averrhoa Bilimbi L) Dan Ekstrak Daun Pepaya (Carica Papaya L.) Pada Mencit (Mus musculus) Amran," As-Syifaa, vol. 10, no. 02, pp. 213-220, 2018.

[17] A. Nur, D. reski Fajar, And Musdalifah, "Efektivitas Pemberian Rebusan Daun Pandan Wangi (Pandanus Amaryllifolius Roxb.) Terhadap Penurunan Kadar Glukosa Darah Mencit (Mus Musculus) Effectiveness," Media Farm., vol. XV, no. 2, p. 9, 2018.

[18] A. Nur, "Uji Efek Analgetik Dan Antiinflamasi Ekstrak Etanol 70\% Daun Beruwas Laut (Scaevola taccada (Gaertn.) Roxb.) PADA TIKUS PUTIH (Rattus," Media Farm., vol. 14, pp. 6-11, 2018. 